New North Star, 2021; 3:13-28

\title{
Frederick Douglass's Gradual and Sincere Shift on the U.S. Constitution
}

\author{
Joey Barretta \\ Hillsdale College
}

\section{Prologue: Radical Shift or Refinement?}

Frederick Douglass "hated the Constitution until the moment he decided to worship it," historian James Oakes tersely states. ${ }^{1}$ This is true regarding his public work, so it is initially a tempting conclusion. However, it is an oversimplification. Paul Finkelman claims that Douglass changed his view primarily out of expediency rather than some sort of inconsistency, but this is also not a sound interpretation. ${ }^{2}$ Douglass's changing assessment of the Constitution is accounted for within many scholarly books and articles, but the reasons for his shift are either misunderstood or not examined in sufficient detail. Douglass initially subscribed to William Lloyd Garrison's claim that the Constitution was a proslavery compact with the devil. A decade after first meeting Garrison, however, he would become a staunch defender of the Constitution by utilizing a strictly textual interpretation of the document. Though he attained a prominent reputation when joining with Garrison, Douglass remained in a subservient position under his wing, a key point that must be examined when accounting for his shift of opinion. There is evidence that Douglass's faithfulness to Garrisonian orthodoxy regarding the Constitution was not as rigid as his public statements suggest, specifically as seen in his recounting of his time with the Garrisonians. This article will explain the motivations for Douglass changing his view and describe the content of his constitutional thought during and after the break with Garrison to convey the gradual and sincere nature of his change of opinion.

Douglass's turn from rejection to support of the Constitution occurred over several years. Initially, his perspective was primarily shaped by his personal experience, and his visceral hatred of America was amenable with the Garrisonian conception of a proslavery Constitution. America had legally permitted slavery, so the founders and the regime they devised must have supported slavery, too. Douglass's 1851 "Change of Opinion Announced" editorial would be the first time he publicly endorsed the Constitution as antislavery. This pro-Constitution stance became a cornerstone of Douglass's political thought for most of the remainder of his public life, and it is the position he took in many of his most enduring speeches and writings. As James Colaiaco notes, "His acceptance of the political process was not opportunism, as the Garrisonians charged. Douglass never abandoned his moral goals. He merely altered the means by which they might be implemented." 3 In other words, Douglass saw that the anti-political methods of the Garrisonians were ill-suited to attain his goal of abolition. Philip S. Foner further explains, "Step by step

\footnotetext{
I would like to extend my gratitude to Dr. Kevin Portteus of Hillsdale College and Prof. Casey Wheatland of Texas State University for commenting on earlier iterations of this article. The team at the New North Star gave extensive feedback, helping me strengthen my argument. Dr. John McKivigan, in particular, provided useful secondary literature that has been incorporated into this final version.

1 James Oakes, The Radical and the Republican: Frederick Douglass, Abraham Lincoln, and the Triumph of Antislavery Politics (New York: W. W. Norton, 2007), 92. Oakes includes this line as part of a general description of Douglass as inconsistent and emotional in contrast to the more stolid Abraham Lincoln.

2 Paul Finkelman, "Frederick Douglass's Constitution: From Garrisonian Abolitionist to Lincoln Republican," Missouri Law Review 81, no. 1 (Winter 2016): 64.

${ }^{3}$ James A. Colaiaco, Frederick Douglass and the Fourth of July (New York: Palgrave Macmillan, 2006), 77.
} 
Douglass arrived at the conclusion that there was no need to dissolve the Union. He saw clearly that disunion would isolate the slaves and leave them at the mercy of their masters." 4 Foner accurately describes Douglass's change as gradual and does not question his sincerity, but he offers an incomplete account of how the natural rights philosophy of the American Founding furthered Douglass's shift. Douglass's end always remained the same, but he came to see the Constitution and Union as key to attaining the abolition of slavery, for reasons both practical and principled.

Scholarship that depicts the change of opinion tends to relegate it to a section within a larger treatment, but it is my contention that Douglass's political thought cannot be understood without making the nature and content of his shift clear. Without explaining the break with Garrison first, one may select texts from earlier or later in Douglass's career that align with their own views, rendering a correct interpretation of Douglass's political thought unlikely. Nick Bromell offers one of the more extended treatments of Douglass's shift in a chapter from his book The Powers of Dignity, but his representation of the content of Douglass's political philosophy is somewhat mistaken. The core of Bromell's depiction is encapsulated in this line: "On the one hand, he insisted on the intellectual and ethical legitimacy of changing his mind, so long as such seeming inconsistency was actually guided by a 'fixed principle of honesty." "5 Bromell uses Douglass's own words here to show that he was not simply inconsistent, even explaining that historians are mistaken in depicting his ideological shift as such. He explains that Douglass believed "citizens should regard their democracy as never fully achieved and always open to revision." The problem with Bromell's treatment is that he depicts Douglass as akin to a philosophic Progressive with respect to this notion of change and historical contingency. He claims that Douglass believed in a higher law, but also that individual people inevitably are self-interested, and thus incapable of ascertaining this law without bias rooted in their own historical circumstances. Rather, this essay argues that Douglass understood the unchanging nature of justice and believed that natural rights could be ascertained by rational human beings. This means that, while perhaps flexible in approach, he foresaw a fixed end with human interests directed toward a more noble existence. Bromell concludes this chapter: "Therefore, while the citizens of democracy must be guided by fixed and eternal truths, the only secure foundation of their polity is a principle of flexibility and openness to difference; only such a principle can welcome and harmonize the contingency and pluralism that any flourishing democracy rightly produces." Douglass believed that there were fixed principles of justice that could be attained, so this notion of flexibility must be taken in light of this fact. ${ }^{7}$ Douglass was a reformer in the pursuit of the realization of natural rights of selfgoverning human beings that transcend time and place but have been uniquely engrained within the American Founding, specifically in its principles and republican institutions.

\footnotetext{
${ }^{4}$ Philip S. Foner, "Frederick Douglass" in The Life and Writings of Frederick Douglass: Volume 2, Pre-Civil War Decade, ed. Philip S. Foner (New York: International Publishers, 1975), 53.

${ }^{5}$ Nick Bromell, The Powers of Dignity: The Black Political Philosophy of Frederick Douglass (Durham, N.C.: Duke University Press, 2021), 118.

${ }^{6}$ Bromell, The Powers of Dignity, 123.

${ }^{7}$ This will be discussed in greater detail later. Douglass's response to the Dred Scott case is especially illuminating regarding the importance of Founding principles and constitutional provisions.
} 


\section{Frederick Douglass, Garrisonian Purist}

Frederick Douglass's initial Garrisonianism resulted in large part from his experience under the institution of slavery during his formative years. Following his time in bondage, he thoroughly acquainted himself with the work of William Lloyd Garrison as an avid reader of the Liberator. Garrison's impassioned hatred of slavery and the country that legalized it appealed to Douglass. It was under Garrison's wing that Douglass rose to prominence in public life. Douglass's entrance into the Garrisonian fold provided Garrison with a new opportunity to advance the cause of "moral suasion," a rhetorical strategy that amounted to stirring up the emotions of audiences with righteous anger against the inhumanity of slavery. Douglass's rousing personal tale describing the institution's brutality was clearly useful for this purpose, and he earned a reputation as a great orator while under the tutelage of Garrison.

The profound effects that Garrison and his acolytes had on Douglass as he entered public life cannot be overstated. In a eulogy for Garrison, Douglass described his mindset upon hearing Garrison for the first time. He exclaimed, "I shall never forget the feeling with which I went to hear this man: I was only a few months from the house of bondage.... In him I saw the resurrection and life of the dead and buried hopes of my long enslaved people." 8 Garrison was a savior figure to Douglass, and he did his best to advance the Garrisonian cause. David Blight's exhaustive biography of Douglass provides a thorough account of this time with the Garrisonians. Blight astutely notes the way Douglass was perceived at the time: "He was the ornament, the object, the former piece of property who could speak and write, who could match wits and logic with even his most determined critics, a youthful, beautiful brown man who made people think."9 He further explains that this superior intellect was supplemented by the fervor of a preacher seeking repentance from a nation that had permitted the evil of slavery. Douglass's natural talents and religious zeal were shaped, in part, by Garrison's influence. "In the early 1840s," writes Blight, "Douglass did swallow whole the cluster of ideas and strategies the prophetic Garrison had honed into rigid orthodoxy.... Garrison took abolitionism into the realm of Christian anarchy, human moral perfectionism, and rejection of virtually all governmental authority." 10 Yet, this adherence to orthodoxy would prove to be ephemeral. The tenet of the Garrisonian platform that forbade political involvement became untenable to Douglass over time, to such an extent that the man who had been a zealous fan of the Liberator would cross over to the ranks of the political abolitionists.

\section{Written by Himself: Independence Expanded, Orthodoxy Questioned}

To be clear, Garrison provided Douglass the opportunity to utilize his rhetorical skill at a time in which few believed a former slave could speak as eloquently as he did. In 1845, Douglass published his first autobiography, Narrative of the Life of Frederick Douglass, an American Slave, in part to disprove the notion that he had not in fact been a slave. Reflecting back on this time in My Bondage and My Freedom, he writes, "People doubted if I had ever been a slave. They said I did not talk like a slave, look like a slave, nor act like a slave, and that they believed I had never

\footnotetext{
${ }^{8}$ Frederick Douglass, "Eulogy for William Lloyd Garrison” in If I Survive: Frederick Douglass and Family in the Walter O. Evans Collection, eds. Celeste-Marie Bernier and Andrew Taylor (Edinburgh, Scot.: Edinburgh University Press, 2018), 452-53.

${ }^{9}$ David W. Blight, Frederick Douglass: Prophet of Freedom (New York: Simon and Schuster, 2018$), 104$.

${ }^{10}$ Blight, Prophet of Freedom, 104-05.
} 
been south of Mason and Dixon's line."11 Narrative reveals the quality of writer and thinker that Douglass was even early in his public career. Concurrently, it also conveys the harsh reality of his life as a slave, thus disproving the notions of his critics. He expresses a similar sentiment in an 1846 letter to the editor of the Liberator: "But for you, sir, the pro-slavery people in the North might have persisted ... in representing me as an imposter - a free negro who had never been South of Mason \& Dixon's line-one whom the abolitionists, acting on jesuitical principle, that the end justifies the means, had educated and sent forth to attract to their faltering cause." 12 Narrative showed in unflinching detail that he had indeed been a slave, not a free Black assuming the identity of a runaway slave simply to further the Garrisonian agenda.

The way Douglass was treated by the Garrisonians helps explain, in part, why he abandoned their ranks. While he may not have been the imposter that critics charged him to be, Douglass did serve as an instrument for Garrison to display the horrors of slavery. However, he would not tolerate such a limiting position in perpetuity. Douglass relates a telling anecdote in $M y$ Bondage and My Freedom: "It was said to me, 'Better have a little of the plantation manner of speech than not; "tis not best that you seem too learned." "13 While he ascribed the best motivations to his Garrisonian friends in giving such advice, this clearly was not the man Douglass sought to be. He was neither expected nor permitted to fully utilize his intellect and share his own views of how to solve the problem of slavery.

Douglass looked back upon his time with Garrison in My Bondage and My Freedom and Life and Times, sharing similar accounts in both: "My first opinions," he writes in the latter, "were naturally derived and honestly entertained... finding their views supported by the united and entire history of every department of the government." 14 Slavery was legally sanctioned within the Constitution, so he could revere neither the document nor the regime that it devised. He held on to his Garrisonian views when he first encountered ex-Garrisonian Gerrit Smith. ${ }^{15}$ It was Smith who would help fund Douglass's endeavors as a publisher, and it would be in his paper that Douglass could explicate his own thoughts on how to address the end of slavery, unfettered by the limitations of serving in the Garrisonian ranks. ${ }^{16}$

The break with William Lloyd Garrison had been all but finalized with the foundation of Douglass's own newspaper, the North Star, and the turn toward independence that it represented. John R. McKivigan and Rebecca A. Pattillo note that Douglass selected Rochester, New York, as the location to publish the paper, a decision they call "a calculated maneuver by Douglass to get

\footnotetext{
${ }^{11}$ Frederick Douglass, My Bondage and My Freedom in John W. Blassingame and Peter P. Hinks, eds., The Frederick Douglass Papers, Series 2: Autobiographical Writings, 3 vols. (New Haven, Conn.: Yale University Press, 2003), 2:208.

${ }_{12}$ Frederick Douglass to William Lloyd Garrison, 27 January 1846, in John R. McKivigan, ed., The Frederick Douglass Papers, Series 3: Correspondence (New Haven, Conn.: Yale University Press, 2009), 1:83. Douglass is referring to A. C. C. Thompson here in a letter to the editor of the Liberator. While he will offer criticisms of the extract by Thompson published in the paper, Douglass thanks him for confirming the veracity of his Narrative.

${ }^{13}$ Douglass, My Bondage and My Freedom, 208.

${ }^{14}$ Frederick Douglass, Life and Times of Frederick Douglass in John R. McKivigan, ed., The Frederick Douglass Papers, Series 2: Autobiographical Writings, 3 vols. (New Haven, Conn.: Yale University Press, 2012), 3:204. See also My Bondage and My Freedom, 203-205.

${ }^{15}$ John Stauffer, Giants: The Parallel Lives of Frederick Douglass and Abraham Lincoln (New York: Twelve, 2008), 145.

${ }^{16}$ David W. Blight, Frederick Douglass' Civil War: Keeping Faith in Jubilee (Baton Rouge: Louisiana State University Press, 1989), 30.
} 
outside the Garrisonian orbit."17 Blight explains, "The Liberator's founder had opposed Douglass's independent venture, which the young editor called the North Star, from the very inception of the idea." 18 McKivigan aptly describes the arguments the Garrisonians made in opposition. For instance, they said there were other newspapers with Black editors, so it would not be financially viable. "Most significantly," he emphasizes, "some white Garrisonians advised Douglass that he lacked the prerequisite education to be an editor and should stick to lecturing. Underlying all of these arguments was a belief that Douglass, only a few years removed from slavery, still required close tutelage."19 Douglass famously had to teach himself in unorthodox ways due to being prohibited from a formal education while enslaved. This critique was a continuation of the paternalistic position Garrison and his acolytes held over Douglass. They believed he ought to continue lecturing and tell his story in a manner befitting a formerly enslaved person.

The impending break with Garrison was precipitated by the founding of his own newspaper not only because Garrison himself had been in opposition, but also because of the active approach Douglass took regarding politics in his work, even before making the public break in 1851. "Organized political abolitionism was nearly a decade old on June 14, 1848," Blight writes, "when Douglass attended his first official political gathering, a meeting of the National Liberty party in Buffalo." 20 The person at the head of this meeting was Gerrit Smith. Smith would serve as a key figure in Douglass's life; beyond encouraging him to attend his first political meeting, Smith also helped fund Douglass's publications and became a good friend. However, Douglass maintained the Garrisonian view of the Constitution at this meeting. As McKivigan describes, "Called on by the delegates to address them, Douglass had disappointed them when he declared his loyalty to the Garrisonian view that the Constitution supported slavery and his refusal to vote under it."21 Douglass had entered political life in a new way by attending this convention centered on electoral engagement, but he demurred on voting himself, maintaining that the Constitution was irredeemably corrupted.

Two months later, Douglass attended the convention of the Free Soil Party, which represented a different approach to countering slavery. Waldo E. Martin Jr, raises an intriguing point about the contradiction between Douglass's Garrisonianism and his practical turn: "Interestingly enough, however, Douglass's increasing involvement with political abolitionists and in their activities, all the while vowing his firm commitment to Garrisonian political and constitutional principles, disclosed his growing awareness that political means might just assist abolitionism." 22 This is indicative of the fact that Douglass did indeed change his political alliances, but he remained steadfast in his principles. Rather than engage in acts of moral piety, Douglass did intend for the reforms he sought to be implemented, and he would join with those who would help the cause. While the Liberty Party was more ideologically aligned with Douglass

\footnotetext{
17 John R. McKivigan and Rebecca A. Pattillo, "Autographs for Freedom and Reaching for a New Abolitionist Audience," The Journal of African American History 102 no. 1 (Winter 2017), 36.

${ }^{18}$ Blight, Prophet of Freedom, 188.

${ }^{19}$ John R. McKivigan, "The Frederick Douglass-Gerrit Smith Friendship and Political Abolition in the 1850s," in Frederick Douglass: New Literary and Historical Essays, ed. Eric J. Sundquist (Cambridge, Eng.: Cambridge University Press, 1990), 207.

${ }^{20}$ McKivigan, "Frederick Douglass-Gerrit Smith Friendship," 28.

${ }^{21}$ John R. McKivigan, "Frederick Douglass and the Abolitionist Response to the 1860 Election," in The Election of 1860 Reconsidered, ed. A. James Fuller (Kent, Ohio: Kent State University Press, 2013), 147.

${ }^{22}$ Waldo E. Martin, Jr., The Mind of Frederick Douglass (Chapel Hill, N.C.: University of North Carolina Press, 1984), 33.
} 
on the need for national abolition, he believed that the Free Soil Party had a better chance of success. ${ }^{23}$ The Free Soil Party sought to limit the growth of slavery into western territories, which Douglass, and even Garrison, thought to be compromised in principle but politically possible. Gerrit Smith and the Liberty Party maintained that slavery was unconstitutional. Although the Liberty Party was deemed by Douglass to have poor prospects for victory in this cycle, Douglass would find Smith's constitutional theory to be persuasive over time. What he had deemed as an exercise of ideological purity on Smith's part at the time, almost paradoxically given his own refusal to vote, he would later interpret as correct and useful for practical success.

Smith's role in Douglass's conversion to independent political abolitionist cannot be overstated. His support of Douglass as a newspaper editor is simply one example of Smith's continual faith in Douglass, the man who had retained the Garrisonian line on the Constitution during the Liberty Party convention just a few years prior. McKivigan describes Smith's role in founding Frederick Douglass' Paper through his proposal of a merger between the North Star and the Liberty Party Paper in 1851. ${ }^{24}$ Smith sought to revitalize the Liberty Party, believing that having Douglass as editor of the combined entity would benefit the party greatly by converting more Free Soilers to his position on national abolition. It would also help to solidify Douglass's turn toward political abolitionism following his public break with Garrison. McKivigan explains, "Smith deferred to Douglass in arranging the merger. The final terms of these negotiations made it clear that that Douglass intended to make the new newspaper unmistakably his own." ${ }^{25}$ Smith, ever the supporter of Douglass, consented to this arrangement. The financial support and merger of papers represented the extent to which Smith held Douglass in esteem and the lofty role he thought Douglass ought to occupy in the fight for abolition throughout the country.

Douglass's relationships with Garrison and Smith stand in sharp contrast. While the former operated from a paternalistic position of superiority, employing Douglass as a means for the end of moral suasion, the latter showed Douglass great respect, even when they disagreed. Diana Schaub describes Douglass's growing dissatisfaction under Garrison: "He wanted not only to retell his story, but to assess and explain it, to speak to the larger meaning of slavery, and the proper course and tactics of the fight against it." ${ }^{26}$ Smith was willing to debate Douglass, and they did so with mutual respect and cordial disagreement. "While Garrison had treated Douglass like a son," John Stauffer concludes, "Smith became a friend and ideal colleague. Douglass found that he could argue with and oppose Smith on important issues without recrimination." 27 They had intense arguments over the place of slavery in the Constitution and the intentions of the founders. The Garrisonians were outraged when Douglass aligned with Smith. As McKivigan explains, "His former Garrisonian friends denounced Douglass's apostasy and accused him of being bought out by the wealthy Smith." 28 Nevertheless, despite these charges, Smith never coerced Douglass to join his side on this issue, in public or private writings alike.

\footnotetext{
${ }^{23}$ McKivigan, "Abolitionist Response to the 1860 Election," 147.

${ }^{24}$ McKivigan, "Abolitionist Response to the 1860 Election," 215.

${ }^{25}$ McKivigan, "Abolitionist Response to the 1860 Election," 215.

${ }^{26}$ Diana J. Schaub, "Frederick Douglass's Constitution," in The American Experiment: Essays on the Theory and Practice of Liberty, eds. Peter Augustine Lawler and Robert Martin Schaefer (Lanham, Md.: Rowan \& Littlefield, 1994), 460.

27 John Stauffer, "Douglass's Self-Making and Abolitionism," in The Cambridge Companion to Frederick Douglass, ed. Maurice S. Lee (Cambridge, Eng.: Cambridge University Press, 2009), 22.

${ }^{28}$ McKivigan, "Abolitionist Response to the Election of 1860," 150.
} 
Instead of compromising with slaveholders by interpreting the Constitution in light of the framers' original intentions, ${ }^{29}$ Smith concentrated on the meaning of the words and how they could be applied to the abolitionist cause ${ }^{30}$ Four months prior to his conversion from Garrisonianism, Douglass wrote Smith explaining why he could not follow his example: "I am sick and tired of arguing on the slaveholders' side of the question, although they are doubtless right so far as the intentions of the framers of the Constitution are concerned. But these intentions you fling to the winds." 31 Douglass already believed that the Garrisonian view was the same as the slaveholders' interpretation. The framers intended for the Constitution to support slavery, according to members of both the Garrisonian and proslavery factions. Douglass maintained that understanding the intent of the framers was the critical point to interpreting the Constitution, while Smith sought a close examination of the text itself. Finkelman claims that "Douglass was easily drawn to Gerrit Smith's brand of political activism and his willingness to confront slavery directly." 32 The evidence shows that there was a protracted debate between the two before Douglass publicly changed his mind. ${ }^{33}$ According to Finkelman, "By 1851, Douglass was committed to practical attacks on slavery, rather than historically accurate theoretical discussions of the Constitution." 34 The problem with Finkelman's account is that it implies that Douglass was either disingenuous ${ }^{35}$ or willing to simply ignore historical fact, but Douglass's refined views on the Constitution both acknowledge harsh realities of slavery while also providing a comprehensive philosophical interpretation of the American regime. Douglass knew the atrocities of which he spoke, but he also believed that the principles upon which this nation was based were diametrically opposed to slavery, an institution incompatible with civil society itself.

Douglass's time with the Garrisonians was prolonged by his feeling unable to refute their arguments. In Life and Times, he describes his state of mind leading up to his break with Garrison: "I was bound not only by their superior knowledge to take their opinions in respect to this subject, as the true ones, but also because I had no means of showing their unsoundness." 36 Douglass here indicates he had his doubts even while remaining aligned with the Garrisonians. Given his time under slavery and his position as storyteller to the White audience, this reluctance to fully commit to his own thought is understandable. Though his eulogy for Garrison was generally positive, there was an implicit criticism made most clear in his handwritten manuscript from the Walter O. Evans Collection: "This is not the time and the place for a critical, and in every sense, an accurate measurement of William Lloyd Garrison, but no friend of his, has need to fear the application to

\footnotetext{
${ }^{29}$ See Willam M. Wiecek, "Radical Constitutional Antislavery: The Imagined Past, the Remembered Future," in The Sources of Antislavery Constitutionalism in America, 1760-1848, (Ithaca, N.Y.: Cornell University Press, 1977), 249275. Douglass cites William Goodell, Lysander Spooner, and Gerrit Smith as influences in his "Change of Opinion Announced" editorial. Smith is the focus of this article because of his unique connection to Douglass both as a friend and benefactor. Goodell, Spooner, and other radical constitutionalists are given an extended treatment by Wiecek.

${ }^{30}$ Stauffer, Giants, 146.

${ }^{31}$ Frederick Douglass to Gerrit Smith, 21 January 1851, in John R. McKivigan, ed., The Frederick Douglass Papers, Series 3: Correspondence (New Haven, Conn.: Yale University Press, 2009), 1:438 (emphasis added).

${ }^{32}$ Finkelman, "Frederick Douglass's Constitution," 58.

${ }^{33}$ See Blight, Frederick Douglass' Civil War, 32-33.

${ }^{34}$ Finkelman, "Frederick Douglass's Constitution," 58.

${ }^{35}$ Finkelman implicitly endorses the Garrisonian line that Douglass sacrificed principle in abandoning their ranks. While he does not quite allege that Douglass was a sellout, the criticism is similar in depicting Douglass as an opportunist.

${ }^{36}$ Douglass, Life and Times, 204.
} 
him [of] the severest tests of honest and truthful criticism." 37 This more critical view of Garrison shows the posture of a post-Garrison Douglass. Just as his desire for physical freedom had been kindled upon learning the alphabet as a child, his break with Garrison came when he educated himself and formulated his own conclusions on how to best combat slavery. ${ }^{38}$

\section{"Change of Opinion Announced" and "What to the Slave is the Fourth of July?"}

Four months after his refutation of Smith's pro-Constitution view in the previously cited letter, Douglass made a public proclamation of his reformed interpretation of the Constitution. No longer would he focus on original intent outside of the text or apply his personal experience to constitutional interpretation, he would examine the text of the document itself, following the example of Smith. Blight explains, "By early 1849, he had stepped beyond the hardened Garrisonian conception of the Constitution as a proslavery compact with evil." 39 Blight examines an 1849 letter to Salmon P. Chase in which Douglass admits that a textual reading of the document would render it antislavery, "although the 'original intent' of the founders and the meaning given it to the Supreme Court had made it so." ${ }^{40}$ Douglass arrives at a different conclusion in the 1851 editorial. Speaking for himself and the stance of his paper, Douglass declares, "We found, in our former position, that, when debating the question, we were compelled to go behind the letter of the Constitution, and to seek its meaning in the history and practice of the nation under it." ${ }^{11} \mathrm{He}$ would now be able to assume a more active role in shaping political opinion after accepting the Constitution as antislavery and worthy of praise, rather than proslavery in original intent and historical practice. Intent would be derived from the text itself.

While Garrison decried the basis for this nation, Douglass's positive interpretation of the Founding permitted him to counter the institution of slavery through the legitimate realm of politics, which the Garrisonians had eschewed. As a pro-Constitution political abolitionist, Douglass explained that the "first duty of every American citizen, whose conscience permits him so to do, to use his political as well as his moral power for its [slavery's] overthrow." 42 In his former position, he focused on the moral depravity of slavery that transforms men into inhuman beasts. Douglass maintained this perspective on the nature of slavery in his second autobiography, published after the shift, writing that the "grand aim of slavery" is "always and everywhere ... to reduce man to a level with a brute." 43 Slavery has a deleterious effect on both master and slave. The Constitution and Union were meant to protect the rights of all men as human beings, so the institution was in contradiction to the guiding principles of the regime. It must necessarily be abolished for the nation to endure. He not only instructed his readers to understand the immorality of slavery but also encouraged them to advocate for slavery's elimination at the ballot box. "Once he rejected the proslavery reading of the Constitution accepted by the Garrisonians," writes

\footnotetext{
${ }^{37}$ Frederick Douglass, "Eulogy for William Lloyd Garrison," in Celeste-Marie Bernier and Andrew Taylor, If I Survive: Frederick Douglass and Family in the Walter O. Evans Collection (Edinburgh, Scot.: Edinburgh University Press, 2018), 450-451 (strikethrough in original manuscript).

${ }^{38}$ See Frederick Douglass, Narrative of the Life of Frederick Douglass, an American Slave in John W. Blassingame and Peter P. Hinks, eds., The Frederick Douglass Papers, Series 2: Autobiographical Writings, 3 vols. (New Haven, Conn.: Yale University Press, 1999), 1:33-34.

${ }^{39}$ Blight, Frederick Douglass' Civil War, 32.

${ }^{40}$ Blight, Frederick Douglass' Civil War, 32.

${ }^{41}$ Frederick Douglass, "Change of Opinion Announced," North Star, 23 May 1851.

${ }^{42}$ Douglass, "Change of Opinion" (original emphasis.)

${ }^{43}$ Douglass, My Bondage and My Freedom, 23.
} 
Nicholas Buccola, "he began to view the Constitution as an important statement about the aims of the American union." 44 In other words, Douglass concluded that the ends of the Union were just, so he could appeal to what he deemed to be worthwhile aims in the pursuit of abolition.

Slavery could not be reconciled with the text of the Constitution, in Douglass's estimation. Douglass wrote to Smith after his "conversion editorial" was published with a different view of how to understand the framers' intentions: "I had not made up my mind then," Douglass described, "as I have now, that I am only in reason and in conscience bound to learn the intentions of those who framed the Constitution in the Constitution itself." 45 Douglass had previously evaluated the intentions of the framers based on his experience with slavery and his time with the Garrisonians. Finkelman changes this formulation: “Douglass acknowledged he had learned much from Smith's constitutional analysis and was ready to endorse Smith's constitutional theory, which allowed him 'fling to the winds' the 'intentions' of the framers." 46 Finkelman quotes Douglass's criticism of Smith to describe why Douglass no longer cared about original intent, but Douglass himself explained that intent is manifested in the content of the text. Douglass assessed the framers' intentions through the words they wrote in the Constitution rather than the implementation of the document or the personal conduct of those framers, a consistent view he held publicly from 1851 until the end of his life.

Douglass had stressed political involvement as the crucial action necessary to actualize abolition in his "Change of Opinion Announced" editorial, and he expands on this in the year following in perhaps his most famous speech, "What to the Slave is the Fourth of July?" In this speech, Douglass articulates how America strayed from its Founding, but it could be redeemed by upholding the principles that formed the basis of its political institutions. Douglass exclaims, "Your fathers have lived, died, and done their work, and have done much of it well. You live and must die, and you must do your work." 47 Throughout this speech Douglass rhetorically divides his audience by referring directly to White listeners as "you." For Douglass, the anniversary of the Founding revealed that the country had not always sufficiently included the Black man in practice, but that does not mean this was by design. On the contrary, he exhorts his White audience to take action in order to fully realize the principle of equality espoused by the founders in the Declaration. He offers them a criticism and a warning: "The existence of slavery in this country brands your republicanism as a sham, your humanity as a base pretense, and your Christianity as a lie . . . [it is the] only thing that seriously endangers your Union."48 Since the principles of the Union's Founding were not proslavery in design, the institution of slavery had corrupted the country to such an extent that it constituted an existential threat to the Union. Charles W. Mills, like Finkelman, rejects the post-1851 Douglass in his analysis of the speech; Mills writes, "Douglass was obviously mistaken about his own time and a century after his death his prognosis has yet to be fulfilled. In short, everything Douglass said is wrong." 49 Mills believes that Douglass was right

\footnotetext{
${ }^{44}$ Nicholas Buccola, The Political Thought of Frederick Douglass: In Pursuit of American Liberty (New York: New York University Press, 2012), 134.

${ }^{45}$ Frederick Douglass to Gerrit Smith, 21 May 1845, in John R. McKivigan, ed., The Frederick Douglass Papers, Series 3: Correspondence (New Haven, Conn.: Yale University Press, 2009), 1:448 (original emphasis).

${ }^{46}$ Finkelman, "Frederick Douglass's Constitution," 58.

${ }^{47}$ Frederick Douglass, "What to the Slave is the Fourth of July?: An Address Delivered in Rochester, New York, on 5 July 1852," in John W. Blassingame, ed., The Frederick Douglass Papers, Series 1: Speeches, Debates, and Interviews, 4 vols. (New Haven, Conn.: Yale University Press, 1982), 2:366.

${ }^{48}$ Frederick Douglass, "What to the Slave is the Fourth of July?," 383 (original emphasis).

${ }^{49}$ Charles W. Mills, "Whose Fourth of July? Frederick Douglass and 'Original Intent'," in Frederick Douglass: A Critical Reader (Malden, Mass.: Blackwell Publishers, 1999), 134.
} 
when he said the holiday belonged to the White man, but every argument Douglass made that suggested this could be transcended was wrong. Douglass expressing an independent Black will is more significant than his mistaken opinions, according to Mills ${ }^{50}$ However, the arguments Douglass provides are thoughtful and worthy of a more thorough explication.

Douglass divides his audience between "you" and "us" in this speech, which initially appears to firmly separate him from his White listeners. ${ }^{51}$ However, he also makes clear that his linguistic separation does not mean that this split was inherent in the design of the regime, nor must it remain in perpetuity. The Founding was based on equal natural rights as espoused in both the Declaration of Independence and Preamble of the Constitution, and the work of the founders was noble in principle, according to Douglass. Thus, he saw himself as an advocate for the equitable application of the principles of the Founding. An example of his view is shown in his description of the founders as peaceful men except when questions of justice arose: "They showed forbearance; but that they knew its limits. They believed in order; but not in the order of tyranny. With them, nothing was 'settled' that was not right. With them justice, liberty and humanity were 'final'; not slavery and oppression." 52 The founders were not satisfied with any injustice. Accordingly, slavery was a major obstacle to achieving the justice enshrined in the Declaration of Independence. To that end, Douglass believed the American Founding would only be fully realized when man's fundamental natural rights were equally protected for all, regardless of race. It was the task of the people to carry on the good, although incomplete, work of the authors and signers of the Declaration and Constitution by furthering the conception of equality enshrined in the former and the republican self-government established in the latter. ${ }^{53}$

\section{The Evolution of Douglassian Constitutionalism: Interpreting the Slavery Clauses}

In his final autobiography, Douglass reflects on how he fundamentally shifted his view and rejected Garrisonianism: "This radical change in my opinions produced a corresponding change in my action. To those with whom I had been in agreement and sympathy," Douglass explains, "I came to be in opposition. What they held to be a great and important truth I now looked upon as a dangerous error." 54 He was opposed to the Garrisonians' singular focus on abolition, denunciation of the Union, and refusal of active political involvement. Douglass proclaimed that this was hazardous and to clamor for the destruction of the Union was to forsake the possibility of abolition being realized. The Constitution was not a proslavery document, according to Douglass, in an 1860 speech delivered in Glasgow, and to portray it as such was to destroy any hope for abolition: "I, on the other hand, deny that the Constitution guarantees the right to hold property in men, and believe the way, the true way, to abolish slavery in America is to vote such men into power as will

\footnotetext{
${ }^{50}$ Mills, "Whose Fourth of July?," 135.

${ }^{51}$ See Sarah Meer, "Douglass as Orator and Editor," in The Cambridge Companion to Frederick Douglass, $52-54$. Meer gives a good treatment of the rhetorical power of the speech. Most importantly, she describes how the audience would have expected a more celebratory address in recognition of Independence Day.

52 Douglass, "What to the Slave is the Fourth of July?," 364-365 (original emphasis.)

53 See Peter C. Myers, Frederick Douglass: Race and the Rebirth of American Liberalism (Lawrence, Kans.: University Press of Kansas), 93-95. Myers explains how and why Douglass appealed to the Preamble to draw a connection between the positive law of the Constitution and the natural law contained in the Declaration of Independence.

${ }^{54}$ Douglass, Life and Times, 204.
} 
exert their moral and political influence for the abolition of slavery." 55 This emphasis on voting antislavery men into office was demonstrative of Douglass's positive view of the Constitution because he not only saw that it was antislavery, but also that active civic engagement within the republican form of government it established was the means by which to end slavery. As he explained in his Fourth of July address, the work of the founders was good, and the succeeding generations must assume their civic duty to vote good antislavery men into office who would continue the work of the founders.

An examination of an 1849 essay from the North Star contrasted with the 1860 Glasgow speech $^{56}$ is useful to better understand the content of Douglass's thought on specific provisions in the Constitution and to demonstrate the extent of his change in opinion. ${ }^{57}$ In 1849's "The Constitution and Slavery," Douglass provides detailed analyses of several clauses of the Constitution and shows why each is proslavery in a Garrisonian fashion. In his 1860 Glasgow speech he takes the opposite approach and gives detailed reasons as to why the clauses were antislavery. The Glasgow speech took place after his conversion to Smith's brand of political abolitionism, and, in fact, it was Smith whom he had been refuting in 1849. The Garrisonian Douglass begins his searing critique by describing the state of the slave interest during the writing and ratification of the Constitution. He opines, "Slavery existed before the Constitution, in the very States by whom it was made and adopted.-Slaveholders took a large share in making it. It was made in view of the existence of slavery, and in a manner well calculated to aid and strengthen that heaven-daring crime." 58 Slavery was inherent within the document they produced, and thus it could not be separated. The proslavery faction had a hand in creating the government with the express intent of preserving their "peculiar institution," and they were successful. Slavery existed in the states that ratified the Constitution and there were slaveholders who participated in writing it, so to say the Constitution was anything but proslavery was a grave error, posited the Garrisonian Douglass.

He proceeds to examine the clauses the slaveholding authors conceived. The clauses he addresses include the Three-Fifths Clause, the Importation Clause, the Fugitive Slave Clause, Congress's power to "suppress insurrections," and the Full Faith and Credit Clause, which includes a reference to protection from invasion within the states. ${ }^{59}$ On the Three-Fifths Clause Douglass writes, "A diversity of persons are here described-persons bound to service for a term of years, Indians not taxed, and three-fifths of all other persons. Now, we ask, in the name of common sense, can there be an honest doubt that, in States where there are slaves, that they are included in this basis of representation?"60 This clause is straightforward, according to Douglass. It was designed to bolster the representation of those who held slaves. The "all other persons" meant slaves, and this was made clearer by separating "free" from "all other persons." Not only did this clause give more representation to the South but it could also stand to benefit the North through

\footnotetext{
${ }^{55}$ Frederick Douglass, "The American Constitution and the Slave: An Address Delivered in Glasgow, Scotland, on March 26, 1860," in John W. Blassingame, ed., The Frederick Douglass Papers, Series 1: Speeches, Debates, and Interviews, 4 vols. (New Haven, Conn.: Yale University Press, 1985), 3:346.

${ }^{56}$ See Myers, Frederick Douglass: Race and the Rebirth, 91. It is important to note that Douglass gave this speech in response to George Thompson, the most prominent British Garrisonian, who had criticized him for being ideologically inconsistent.

${ }^{57}$ In reading several treatments of Douglass's shift, the evident points of contrast in the 1849 essay and the Glasgow speech have not been described.

${ }^{58}$ Frederick Douglass, "The Constitution and Slavery," North Star, 16 March 1849.

${ }^{59}$ U.S. Constitution: Art. 1, Sec. 2; Art. 5, Sec. 8; Art. 1, Sect. 2; Art. 4, Sec. 2; Art. 4, Sec. 4.

${ }^{60}$ Douglass, "The Constitution and Slavery" (original emphasis.)
} 
the provision allowing them to levy a ten-dollar tax on each imported slave. The Importation Clause was "a full, complete and broad sanction of the slavetrade for twenty years" that served to appease slaveholders, including Mr. Rutledge of South Carolina, whom Douglass quotes as saying, "If the Convention thinks that North Carolina, South Carolina, and Georgia, will ever agree to the plan, unless their right to import slaves be untouched, the expectation is vain." 61 The Importation Clause was designed to appeal to these proslavery forces by guaranteeing their right to import slaves, as Rutledge explained. It was clearly intended to be a proslavery measure that the "doughface North" succumbed to "just as they have been ever since on all questions touching the subject of slavery." 62 The Fugitive Slave Clause was "adopted with a view to restoring fugitive slaves to their masters - ambiguous, to be sure, but sufficiently explicit to answer the end sought to be attained." 63 The power of Congress to suppress insurrections was meant to address the possibility of slave revolts, Douglass claims. The Full Faith and Credit Clause "pledges the national arm to protect the slaveholder from domestic violence, and is the safeguard of the Southern tyrant against the vengeance of the outraged and plundered slave." ${ }^{2}$ Protection of inhuman bondage was the pervasive feature of the Constitution. He believed the Union was not worth engaging with politically because its foundation was intrinsically corrupt.

The rights and privileges of the Constitution were only granted to the Whites who were responsible for its ratification. "The parties that made the Constitution," Douglass explains, "aimed to cheat and defraud the slave, who was not himself a party to the compact or agreement. It was entered into understandingly on both sides." ${ }^{25}$ The slave was not a party in the formation of the Constitution, so he was never meant to share in its rights and privileges. The proslavery men had sapped the morality out of the Founding to serve their own ends by affording such extensive protections to the slave interest. Slaves were treated as property and not party to the compact. Consequently, it should not be viewed as binding to them. The slave was included within the text only in the context of perpetuating his servitude. It preserved the importation of slaves, gave the slaveholding states more representation, prevented slaves from escaping to freedom, and it even provided a financial benefit to the North through the ability to tax imported slaves as articles of property, argued Douglass.

His early Garrisonianism was on full display in this 1849 editorial, but his pro-Constitution views subsequently led him to systematically counter these earlier claims. While he had come to view the words of the text as sufficient to show the intentions of the framers, he also described the context in which they operated in a way that bolstered an antislavery interpretation of the Constitution. One example is seen in his reformed reading of the infamous Three-Fifths Clausewhich Douglass previously described as a means to boost slave state representation — as "a downright disability upon the slave system of America, one which deprives the slaveholding States of at least two-fifths of their natural basis of representation." 66 The Constitution acknowledged the humanity of the slave by using the description "all other persons" in this system for determining population, thus demonstrating that the South was prohibited from having full representation of all the people within its borders, not that the slave counted as less than a person.

\footnotetext{
${ }^{61}$ Douglass, "The Constitution and Slavery."

62 Douglass, "The Constitution and Slavery."

63 Douglass, "The Constitution and Slavery."

${ }^{64}$ Douglass, "The Constitution and Slavery."

65 Douglass, "The Constitution and Slavery."

${ }^{66}$ Douglass, "The Constitution and Slavery" (original emphasis.)
} 
The Importation Clause is one of the more infamous provisions in the Constitution because it was held by proslavery men (and the Garrisonians) to be a twenty-year protection for the importation of slaves through its prohibiting the abolition of importation until 1808. However, Douglass now interpreted this clause as foretelling future restrictions. It indicated to the proslavery men that importing slaves would cease after they joined the Union. No longer did he believe that this clause was a blanket protection for importation, but rather that it "looked to the abolition of slavery rather than to its perpetuity." 67 The framers looked forward to the end of slavery, and this clause was indicative of this perspective, not a protection of the South's beloved institution, posited Douglass. "At the time the constitution was adopted, the slave trade was regarded as the jugular vein of slavery itself," he continues, "and it was thought that slavery would die with the death of the slave trade." 68 Considering his argument that the Constitution looked to the end of the slave trade, it follows that the framers also were looking forward to the end of slavery.

Contrary to post-Garrison Douglass, Finkelman suggests that William Lloyd Garrison was correct: "On a theoretical level, and on the basis of the actual history of the Founding," writes Finkelman, "it is clear that Garrison always had the better argument. The Constitution of 1787 was overwhelmingly proslavery. It protected slavery at every turn, and it created a slaveholder's Union." ${ }^{69}$ Frederick Douglass effectively countered this view in both his textualist interpretation of the document and in his reflections on the historical events of his day, perhaps most notably the Dred Scott decision. For Douglass, the Constitution was not proslavery, so it was clear that the Garrisonians (and Finkelman) were wrong about the nature of the American Founding. Finkelman disputes the authenticity of Douglass's pro-Constitution views. He believes that Douglass's proConstitution theory was merely a practical construct: "The new Douglass - the politically active Douglass - had to develop a new theory of the Constitution that was consistent with his evolving understanding of the best way to fight slavery." 70 Finkelman does not take Douglass at his word because he finds Garrison's argument more compelling. Peter Myers offers a fairer treatment: "For Douglass, the true meaning of the U.S. Constitution, as of constitutions in general, was fully intelligible only in light of first principles of political life. . . Douglass, along with other political abolitionists, drew upon a venerable tradition of natural-law jurisprudence in fashioning their novel constitutional arguments." "71 There is no reason to question Douglass's sincerity, at least none that is clear when reading Douglass's speeches and writings during his post-Garrison years. He examined the Constitution on both a practical and theoretical level and appealed to a natural law tradition he believed was encapsulated in the principles and institutions of the American Founding.

Guiding the intent of the individual clauses of the Constitution is its Preamble. Douglass traces the intentions of the Constitution as described in the Preamble to show that protection of slavery was not a guiding purpose of the document. Douglass explains, "Union is one, not slavery; union is named as one of the objects for which the constitution was framed, and it is one that is very excellent; it is quite incompatible with slavery. ... Slavery is not among them; the objects are union, defence, welfare, tranquility, justice, and liberty." "72 According to Douglass, slavery was seen as a dying institution by the framers and they wrote clauses that were antislavery in nature; the purpose of the document stood against slavery, which was unjust and antithetical to republican

\footnotetext{
${ }^{67}$ Douglass, "The Constitution and Slavery."

${ }^{68}$ Douglass, "The Constitution and Slavery."

${ }^{69}$ Finkelman, "Frederick Douglass's Constitution," 13-14.

${ }^{70}$ Finkelman, "Frederick Douglass's Constitution," 64.

${ }^{71}$ Myers, Frederick Douglass: Race and the Rebirth, 89.

72 Douglass, "The American Constitution and the Slave," 361.
} 
self-government. Again, according to Douglass, Garrison is incorrect because he does not understand that the framers believed slavery would end gradually. The circumstances that followed simply were not foreseen at the time in which the Constitution was ratified. Finkelman has the benefit of hindsight in his support of the Garrison argument, but he misunderstands the framers' political theory, at least according to later Douglass. Douglass effectively refutes the GarrisonFinkelman mode of interpretation: "This, I undertake to say, is the conclusion of the whole matter - that the constitutionality of slavery can be made only by discrediting the plain, common sense reading of the constitution itself . . . by disregarding the written constitution, and interpreting it in the light of a secret understanding."73 Douglass appeals to the fundamental purposes of the Constitution by examining the text and assesses these purposes in light of the nature of slavery. As he explained in his account at Glasgow, slavery was unjust, antithetical to liberty, and the major existential crisis to the Union.

To claim that the Constitution is proslavery is to say that it provides the means for its own demise, which made no logical sense to Douglass. "The Constitution says 'We the people;' the language is 'we the people;' not we the privileged class," Douglass proclaims, "not we the high, not we the low ... but we the human inhabitants; and unless you deny that negroes are people, they are included within the purposes of this government." 74 While in his 1849 editorial he had disparaged the Constitution for excluding his race, he now applied his textualist interpretation to promote this view of "we the people" as including all people in this country without distinction based on color, class, or creed. The Founding included "we the people" and it was the duty of Americans to act in their political capacity to bring about change. Douglass summarized his reformed reading of the Constitution:

The constitution declares no person shall be deprived of life, liberty, or property without due process of law; it secures to every man the right of trial by jury; it also declares that the writ of habeas corpus shall never be suppressed - that great and noble writ - that writ by which England was made free soil ... We have the same writ, and let the people in Britain and the United States stand as true to liberty as the constitution is true to liberty, and we shall have no need of a dissolution of the Union. ${ }^{75}$

Douglass believed that the protections afforded by the Constitution not only were designed to include all men but could be used to abolish slavery. This portion of the speech echoes the call to political action he gave in 1851. Utilizing the clauses of the Constitution as written, slavery could and must be ended within the political realm, beginning with a citizenry that would support abolition and political leaders who would put this sentiment into practice.

Douglass did not deny the difficulty of his grand vision for abolition. He understood that, although he could show why the Constitution was antislavery, Americans had failed to end slavery up to that point. "But to all this," Douglass declares, "it is said that the practice of the American people is against my view. I admit it. They have given the constitution a proslavery interpretation." "76 Yet, this misinterpretation does not mean the document is proslavery. Douglass then uses the example of the Bible being interpreted against liberty in the United States by the proslavery faction to makes clear that one must not abandon the truth it contained simply because

\footnotetext{
73 Douglass, "The American Constitution and the Slave," 361-362 (original emphasis.)

${ }^{74}$ Douglass, "The American Constitution and the Slave," 361.

75 Douglass, "The American Constitution and the Slave," 362.

76 Douglass, "The American Constitution and the Slave," 362.
} 
it has been misused by devious forces: "What do you do when you are told by the slaveholders in America that the Bible sanctions slavery? Do you go and throw your Bible into the fire? Do you sing out, "No Union with the Bible!'?"77 Certainly not, Douglass concludes in this thinly veiled allusion to Garrison's famous public burning of the Constitution. The political means provided by the Constitution would permit the end of slavery only if the country supported it through the election of sincere antislavery men to the high offices of government. They have failed thus far, but this does not mean it must be this way. The rights protected by the text of the Constitution make slavery an anathema that must be destroyed to preserve the integrity of the country. The writ of habeas corpus had served to abolish slavery in England, so it could also be used in America for the same purpose as it was enshrined by the Constitution. The Constitution included the republican system in which good men could be elected to end slavery and the provisions therein were designed to restrict slavery, so slavery would certainly end, Douglass thought.

The framers believed that slavery was fading, and they provided a Preamble addressing all men along with antislavery clauses to ensure slavery's demise. Claims to moral purity invoked by the Garrisonians proved to be temporary. Basic tenets of the Founding were still engrained within the mores of the people that could be directed against slavery, and this allowed Douglass to describe a remedy for slavery that was in harmony with the Declaration of Independence and the Constitution. As Colaiaco notes, "Douglass's ethical interpretation of the Constitution based upon the document's fundamental liberal principles, made possible political action consistent with the demands of conscience."78 Douglass utilized these principles to interpret the American Founding in a way that he believed was both true and useful for the cause of abolition.

The connection between the Declaration and Constitution made logical sense and proved to be a powerful tool for Douglass's oratory. The "all men" of the Declaration did not discriminate based on race and neither did "we the people" in the Preamble because their purposes are intertwined: the Declaration provided the ideals while the Constitution developed the governing form and institutions to bring the ideals into practice. "Douglass always garnered hope from America's founding creeds," writes Blight, "and in his view the Constitution-its republicanism and protection of individual rights-provided a legal foundation for the earlier promise in the Declaration of Independence. Without this promise and foundation, Douglass' vision of a future for blacks in America would have crumbled." 79 Douglass's hope for America to atone for the sin of slavery depended on the promise of the Declaration of Independence, and this atonement had to be brought about by the American citizenry, as he had described in "What to the Slave is the Fourth of July?" In that speech, he said of the Constitution: "In that instrument I hold there is neither warrant, license, nor sanction of the hateful thing; but, interpreted as it ought to be interpreted, the Constitution is a GLORIOUS LIBERTY DOCUMENT. Read its preamble, consider its purposes. Is slavery among them?" $80 \mathrm{He}$ consistently concludes it is not, at least in his public work beginning in 1851 .

The occasion of the Fourth of July speech was Independence Day, so Douglass's appealing to the Constitution demonstrated his belief that it and the Declaration of Independence must be connected to be understood properly. Near the end of the speech, he exclaims, "I, therefore, leave off where I began, with hope. While drawing encouragement from the Declaration of Independence, the great principles it contains, and the genius of American Institutions, my spirit

\footnotetext{
77 Douglass, "The American Constitution and the Slave," 363.

${ }^{78}$ Colaiaco, Frederick Douglass and the Fourth of July, 93.

${ }^{79}$ Blight, Frederick Douglass' Civil War, 33.

${ }^{80}$ Douglass, "What to the Slave is the Fourth of July?," 385 (original emphasis.)
} 
is also cheered by the obvious tendencies of the age." ${ }^{81}$ This is a hope he maintained even when circumstances were especially dire, as seen in his response to the Dred Scott decision: "In conclusion, let me say, all I ask of the American people is, that they live up to their Constitution, adopt its principles, imbibe its spirit, and enforce its provisions." ${ }^{82}$ The Constitution's text was just and applicable to all Americans, regardless of race, in Douglass's estimation. The principles contained in the Declaration and Constitution would provide the solution he sought, if only the American people would live up to those principles through both their personal conduct and those they selected for office. Douglass maintained his hope that the people could be elevated to pursue the goodness of the country's unique foundation centered around God-given equality.

\section{Frederick Douglass, Prudent American Patriot}

While Douglass's changing his conception of the Constitution, and of America more broadly, may seem abrupt, it was not so much a sudden change but rather a significant refinement of how to best apply his principles over time. Douglass was consistent in his assessments of the dehumanizing effects of slavery. The Declaration of Independence provided a foundation in natural rights, which the Constitution built upon. Thus, Douglass's conversion from the views of Garrison to Smith is not as surprising as it initially appears. The Garrisonians were opposed to political involvement because they believed the regime was illegitimate, so they had no real power to bring about the end of slavery within a republican regime. Abolitionists could not effectively help bring slavery to an end while allied with the Garrisonians. Gerrit Smith and others showed Douglass a more effective model for pursuing abolition through political means. If America did not have the Declaration or Constitution, in Douglass's view, then the end of slavery would have been impossible because of the corrosive effects it had on the people's character, both North and South. The principles of the Founding supplied Douglass with the necessary resources to utilize his natural talents as an orator to unite Americans against the unjust, inhumane, and un-American institution of slavery. His Garrisonian beliefs were sincerely held, but, as he reveals when recounting that period in his latter two autobiographies, he thought for himself and arrived at a different conclusion than the people with whom he initially allied.

\footnotetext{
${ }^{81}$ Douglass, "What to the Slave is the Fourth of July?," 387.

${ }^{82}$ Frederick Douglass, "The Dred Scott Decision: An Address Delivered, in Part, in New York, New York, in May 1857," in John W. Blassingame, ed., The Frederick Douglass Papers, Series 1: Speeches, Debates, and Interviews, 4 vols. (New Haven, Conn.: Yale University Press, 1986), 3:183.
} 